\title{
ARE PEER FEEDBACK ACTIVITY ESSENTIAL IN ONLINE ARGUMENTATIVE WRITING?
}

\author{
Elda Yulia Ryandini \\ English Education and Literature of Postgraduate UNESA \\ eldaryandini16070835065@mhs.unesa.ac.id \\ Oikurema Purwati \\ English Education and Literature of Postgraduate UNESA \\ pungki_unesa@yahoo.co.id \\ Suharsono \\ English Education and Literature of Postgraduate of UNESA \\ suharsono@unesa.ac.id
}

\begin{abstract}
The purposes of this research were to investigate and classify peer feedback activity in online argumentative writing and to probe the essence of getting peer feedback. This research used qualitative approach to respond the research problems. The subjects of this study were 3 students from a writing class of English Education Department at Islamic University in East Java. Data were collected through observation and semi-structured interview. The findings of this research showed that there were various feedback given by peers such as no thesis statement in introduction, short sentences in body and conclusion paragraphs, incomplete ideas in introduction, error grammars and sentence structures, no clear counter arguments and refutations in body paragraphs, no refutation in body paragraph, not cover idea of body paragraph in conclusion, not debatable title, and not confusing position whether agree or disagree with the topic. The result also indicated that the essence of getting peer feedback in online argumentative writing were positive proved by the students' enthusiastic derived from interview.
\end{abstract}

Keywords: Writing, peer feedback, activity; argumentative essay.

\section{A. INTRODUCTION}

\section{Background of Study}

riting activity is different from the other three skills because it involves the
writers' way of generating their ideas. The point is the way how the
writers are able to make the readers move through the text. However, it is not an easy process to accomplish because writing and generating ideas into a text should move smoothly following the organization of a specific writing genre. Writing had become a problem since a half century ago in which many experts declared that it is for recording and for increasing grammatical and lexical characteristic of language (Brown, 2004, p. 218). Nowadays, writing is almost needed for all requirements. Most students are encouraged to write article or publish their writings as a requirement for graduation. It insists them to 
generate, manage ideas, and write well. To overcome this way, students can initially read many sources of writing to know the patterns of English writing as English writing has many different patterns to compose.

As writing activity is quite strict in the composition, it is such a good idea to make students also involve in the activity to proofread and give feedback-to their friends' writings. Peer feedback according to Kearsley (2000, p. 81) as cited in Roberts (Roberts, 2006 , p. 6) stated that feedback conveyed among students is fairly useful since it appears purely from their own standpoint rather than from the expert ones. The most common activity in writing is that students only write according to the topic given by the teacher then submitted and scored without getting other friends' comments involved in. It is also better if the activity is undergone through online media to benefit from less useless use. They are such as social networking sites as many students work on it over 40 hours in a week (Purcell, 2012, p.2) and social media can motivate students in learning because they are comfortable to have a place for communication with peers and lecturers as an educational purpose (Mallia, 2014, p. xxxv). There are various social media which can be used for learning templates by students such as Twitter, Facebook, Blog, Edmodo, Schoology, and Instagram. The teacher can make a group which consists of the students of the class to discuss a subject. They can learn not only the material, but also they can explore the use of the social media. Through online media, it also can make students easy to learn from each other's work. Of all the several of social media, this study is intended to make use of Instagram as a media mostly used by students nowadays for commenting each other in which according to Statista (2019), 71\% of the billion monthly active users are under the age of 35 and the single most popular age range is users between the ages of $25-34$, followed by the users between the ages of $18-24$.

Among studies in the case of the use of Instagram and peer feedbacks in various learning skill activities had been examined previously. A study from Listiani (2016) discussed the comparison between teaching writing recount text using Instagram and teacher-centered on teaching writing recount text for both high and low motivation students using experimental research. The experiments result that using Instagram could significantly helpful for students in improving writing recount text for both high and low motivation students rather than teacher-centered writing. Another study is from Mubarokah (2017) and Kelly (2015) who discussed the use of Instagram for students' writing descriptive text. Results of both studies showed that the use of Instagram could motivate and develop 
students in writing a descriptive text. Al-Ali (2014) tried to integrate Instagram as an active learning tool in a Language Bridge program for a holiday project by involving speaking, writing, and grammar and vocabulary skills by no feedbacks among students. The results showed that the students were not interested in at first, but they slowly welcomed the idea and pushed to be creative in accomplishing the writing activities. Those four studies discussed the use of Instagram for various English writing activities although none of them employed the individual feedbacks for activities using social media of Instagram.

\section{Research Problems}

This brings the study to know whether peer feedbacks activities work in writing activity of English Education Department students in Written Class. This study will try to answer questions of:

1. What feedbacks are given by peers in online argumentative writing?

2. How are the essences of getting peer feedbacks for online argumentative writing?

From the questions above, it is expected that the researchers can get the data related to the feedbacks given in writing, and the essences in getting peer feedback.

\section{Research Objectives}

The objectives of the study are:

1. To investigate and classify peer feedbacks activity in online argumentative writing.

2. To probe the essence of getting peer feedback.

\section{B. REVIEW OF LITERATURE}

\section{Peer Feedback}

In a traditional teaching-learning process, the students acted as passive learner because the teachers dominated the classroom. Students were only instructed to obey teachers' commands. There was rare such an activation of activity except doing exercise in course books and submitted to the teacher to get score. There are some differences in the teachinglearning process nowadays. Since the emergence of K13 which activates the learners in the classroom, teachers only need to monitor students' activity without writing and explaining many things in the classroom. The rule of the K13 curriculum drills the students not to only rely on the teacher's instructions. Most modern teachers try to open mind to the way they teach by adapting the innovative ways such as engaging students to some sources outside the course books. Students must solve the learning problems by their own ways which can encourage them to learn by their own self and their peers. The teacher only monitors the activities and helps the students' difficulties in the classroom. 
Having students as active learners in classroom definitely can help them to activate their ideas how to work collaboratively with their peer, comment to other friends' works, and learn from other friends' accuracy or error. Feedback is someone's opinion regarding the quality of a specific work and it is regarded as a way to encourage students' motivation and to make certain of linguistic accuracy (Tsao et al., 2017, p. 1). According to Nguyen, peer feedback which is also known as peer response or peer review is a collaborative activity of students' reading, critiquing, and giving feedback on one's another writing (Nguyen, 2016, p. 77), and possibly recommend grades for (Roberts, 2006, p. 6) especially in process-based second language (L2) writing classroom (Salih, 2013, p. 42). Feedback also can be done in group or peer because it can improve their interaction skill, increase students' confidence (Roberts, 2006, p. 2), encourage students' contribution in developing students' writing skill (Nguyen, 2016, p. 76), develop critical reflection, listen to and act on feedback, assess and provide feedback sensitively on others' works (Liu \& Carless, 2006, p. 289), and trigger students to pay attention and be serious in learning because they are expected to have reading habit and understand the subjects to be able to give comments to their peer. It is also definitely useful and essential to be used in a classroom with new members who have not known each other yet. According to Hattie and Timperley (2007, p. 82), peer feedback is very beneficial in learning because it can help students be aware of what mistakes they produce in their work and assist them not to repeat the same mistakes in the next works as stated by McConnell (2000, p. 127) cited in Roberts (2006, p. 6)

"... if learners are actively involved in decisions about how to learn, what to learn and why they are learning, and are also actively involved in decisions about criteria for assessment and the process of judging their own and other's work, then their relationship to their studies will be qualitatively different to those learners who are treated as recipients of teaching and who are the object of others', wnilntame1 nnonommant"

Peer feedback is best used both in classroom and in online activity. Many social media can facilitate to activate peer feedbacks such as twitter, facebook, line, or Instagram. This study uses Instagram application to communicate one student to others in the comment column below the picture upload and the argumentative writing. Instagram application is one of many social media applications which can be accessed through smartphone. It is widely used nowadays special for uploading picture or video format. It is closely the same as facebook, but it creates more interesting features than facebook. People can follow each other to share, like, and comment to other posts, on the contrary, people also can private their account from public. There are many features provided such as Instagram story, 
features on instagram story, type mode story, multiple posts, caption and comment column, and direct message feature.

From all features provided on Instagram application, it is interesting to be a means of

online learning which not only creates new and dynamic approaches to the content appearance, but also proposes exciting new ways for students to interact and share learning (Bach et al., 2007, p. 32) through Instagram such as practicing speaking by posting students' videos in their new account or posting pictures to invite someone to write and give comments. It will be effective since Instagram is a social media application to connect with many people and access fruitful information.

\section{Writing Skill}

Writing never becomes an easy and simple activity (Dabbagh, 2017, p. 71). It even becomes challenging despite for advanced learners (Grami, 2012, p. 43). In writing, students need to organize the ideas well into written activity and also to make people understand what the writers want to express. Writing means taking note as a record of something important that needs to be remembered. It is intended to catch the specific idea from the specific audience. Writing also allows people to communicate with others outside the ability of spoken language (Mihalicek \& Wilson, 2011, p. 591) to deliver messages. It is also stated by Horning $(1987$, p. 2$)$ that written language is different from the spoken form in various ways and it becomes an important point of how students increase their writing skills.

To increase students' writing skill, initially students need to know that every good paragraph has a topic sentence and supporting sentence, and some paragraphs also provide a concluding sentence (Oshima \& Hogue, 2006, p. 4-13). The topic sentence discusses the main idea of the paragraph by using a complete sentence which usually appears in the first paragraph or sometimes at the end. When it appears at the final of the paragraph, it is frequently started by some examples (Oshima \& Hogue, 2006, p. 5) and the part of it that states the specific area to be discussed is controlling idea while the supporting sentences build up the topic sentence by providing greater amount of information. The last part of the paragraph is the concluding sentence in which it provides a central thing for readers to remember.

\section{Argumentative Writing}

In argumentative writing, students must provide statements of pro and contra with the good organization. It forces the writer to be critical and stand in a specific position because they try to support the pro argument and rebut the cons argument or on the contrary by providing some facts or examples to convince the readers. Hyland (1990, p. 68) also states that 
argumentative essay is to convince the reader related to the rightness of core thought.

Argumentative paragraph consists of introduction, body, and conclusion. Introductory paragraph contains a thesis statement to give information on the writer's position. The writer must make sure in what position (whether agree or disagree) they are. A thesis statement is usually showing the opposite view and the writer's own view which is put in the independent clause while the opposite is put in the dependent clause (Oshima \& Hogue, 2006, p. 147), such as "despite the claims that learning English is not important for students (opposite view), it is needed for their future because of its importance as an international language (writer's opinion)".

In the body, the expressions to acquaint the opposing points of view are like "some people feel that; many people think that; it may be true that" (Oshima \& Hogue, 2006, p. 148) as a support to convince the readers that other people have other opinions regarding with the issue discussed. The writers must also use the transition signals to indicate the step to another order, signing edition, contrast, condition, or specificity (Hyland, 1990, p. 72). The transition of contrast are showed by however; although/even though; in spite of the fact that/despite the fact that (Oshima \& Hogue, 2006, p. 148) and use connectives for listing arguments, such as firstly which can be applied for the first supporting argument; secondly, furthermore, moreover, in addition can be employed for any supporting arguments (except for secondly); next (Hyland, 1990 , p. 72) and the last is finally as the last supporting argument, but not for concluding connective. The writer can use concluding connectives, such as in conclusion, in summary, and thus as the indication that the writer wants to make finishing statements that cover all the supporting arguments (Daly, 1997).

Research in L2 writing also had undertaken the peer feedback activity among students. Nguyen (2016) stated that students had good desires in the implementation of peer feedback in L2writing classes in which the teacher only informally implemented the feedback activity before. The students got few chances to explore their meta-cognition that finally the study developed a jigsaw peer feedback approach for students. Another study was taken by (Grami, 2012) related to online collaborative writing and feedback checklist using blogs. The result showed that it aided to build up critical thinking and ability in identifying target audience. Overall, these two previous studies resulted in good responses in the practice of peer feedback in writing activity, and this current study wants to explore more related to the peer feedbacks results and their responses in achieving the peer feedback. 


\section{METHOD}

\section{Research Approach}

This study employed a qualitative research approach to respond to the research problems. Qualitative research was for presenting the data through words description in the form of comprehensive content (Miles et al., 2014, p. 30). This study used qualitative approach to answer the research questions through description and explanation of students' peer feedbacks and their responses in achieving peer feedbacks that later the results were explored and described by words in the writing structure. The researchers had divided the students' peer feedbacks according to their attendance list number.

\section{Research Subject}

The subjects of this study were 3 students from one writing class of English Education Department from one Islamic University in East Java. The researcher took this class because the first time the lecturer undertakes feedback activity in the class as previously, the students were only doing writing tasks and getting feedbacks and score from the lecturer.

\section{Data collection Techniques}

In order to collect the data as the key point of this research (Bryman, 2012, p. 12), the researcher used observation and semi-structured interview. The data was done in one session of peer feedback practice and interview. Firstly, the researcher investigated and collect the students' feedback through online writing activity of Instagram application done by other students in the class as chosen by the lecturer to comment on the 3 students' writing. Each writer should write hashtag as agreed in the classroom to ease other peers to find their writings. The following was continued by interviewing the students' responses in achieving the feedbacks from peers. Semi-structured interview was designed to interview specific questions then the participants answer and present new meaning to the study (Galette, 2013, p. 1). The interview was used as the triangulation to know more and enrich the data from more than one point of view (Cohen \& Morrison, 2000, p. 112)

\section{Data Analysis Technique}

Bogdan (2007, p. 159) stated that data analysis as a process which orderly arranges the materials the researchers collect to allow them to move toward findings. This study analyzed the students' various peer feedback in commenting on their friends' argumentative writing on Instagram in a form of written works. Then, the researcher classified the feedbacks conveyed on a comment column of the writer's argumentative essay whether it was correct and essential for the writer or not. The last, the researcher probed the students' answer relating to their responses of essences in getting feedback from their peers in accordance 
Elda Yulia Ryandini, Oikurema Purwati, Suharsono, Are Peer Feedback ...

with argumentative writing on Instagram.

\section{FINDING AND DISCUSSION}

\section{Students' Peer Feedbacks in Writing Activity}

Referring back to the aim of the first question in accordance with feedbacks given by peers in online argumentative writing, this study presented the data relating the students' essays based on a topic from the lecturer "Should Teacher Earn Teaching License to Practice Teaching?". To answer the first problem, the study presents the full text of the writing completed by the feedbacks below the essay in the Instagram.

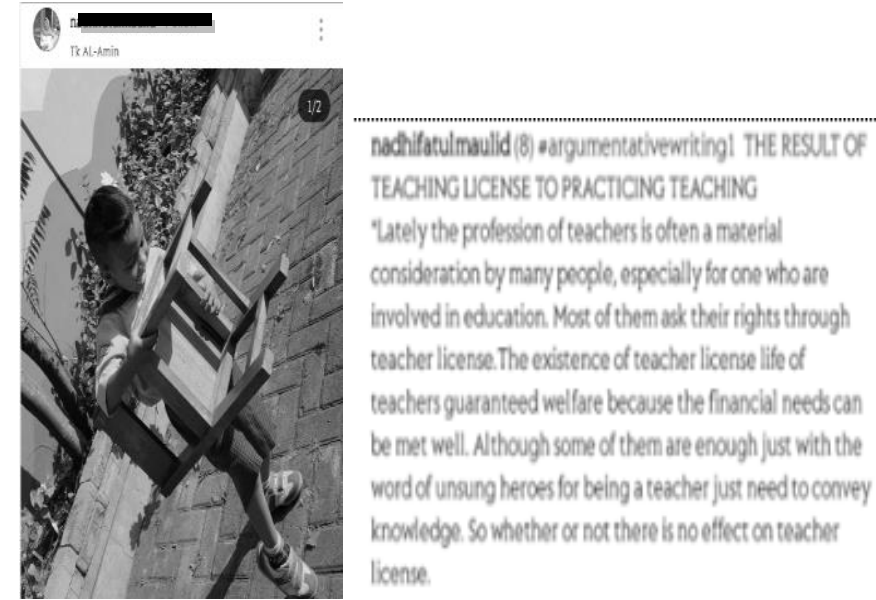

"Teachers are often anxious because the salary is less than the factory employees. Teacher salary is coly earned per month while factory employees receive umr as allowances. As told by prof. Akh Muzakki in one of the campus magazines that a first grade teacher of islamic elementary school in Surabaya earns eight hundred thousand ruplah each month. This indicates that teacher license has not been fully accepted throughout the region. Hownever, the government has attempted to grant teachers rights with the enactment of law no. 14 of 2005 cn teacher license. Thus, teacher license is helpful because teacher license is a financial allowance given every three months of teacher license. "Teacher license is also a peccess of competency test of teachers. So to get license of teachers they must get the requirements that have been determined. However, Not all teachers can get license. Most of them do not qualify because the standard of competence is determined very much but a teacher must have good academic qualicy in accordance with the national education system in Law no 20 of 2003 in order to realize the goals of national education.

Therefore license is important for teachers to get them training and have a good standard accoeding to the growing era.

\begin{abstract}
maulid "The number of license requirements makes teachers difficult. Sometimes, they are more busy taking care of the license process for days. Even the teschers do not mind leaving the class and letting their students get no new knowledge. So the class becomes not conducive. Beyond that, license teaching can manage the class more creatively because they have been practicing how to determine the appropriate method. In addition, they can also prowide competent teaching in accordance with the era required So the generations of champions can be achieved with satisfying potential.
\end{abstract}

"In summary, teacher license is very
important for those who teach. The
existence of teacher lisence makes teacher
economy fulfilled. In addition, the standard
of competence is also tested. So the teaching
can be maximal with very creative and the
students have many opportunities to
become champion. Thus the national
educational goals of the government are
done well.

"In summary, teacher license is very important for those who teach. The existence of teacher lisence makes teacher economy fulfilled. In addition, the standard of competence is also tested. So the teaching can be maximal with very creative and the students have many opportunities to done well.

Figure 1. Student's Argumentative Essay

In the figure above, the student (S8) wrote the complete argumentative writing comprised introduction, 3 body paragraphs, and conclusion discussing the issue of teaching license to practice teaching. Regarding the writing above, most students were encouraged in giving feedbacks related to some aspects as presented below. 


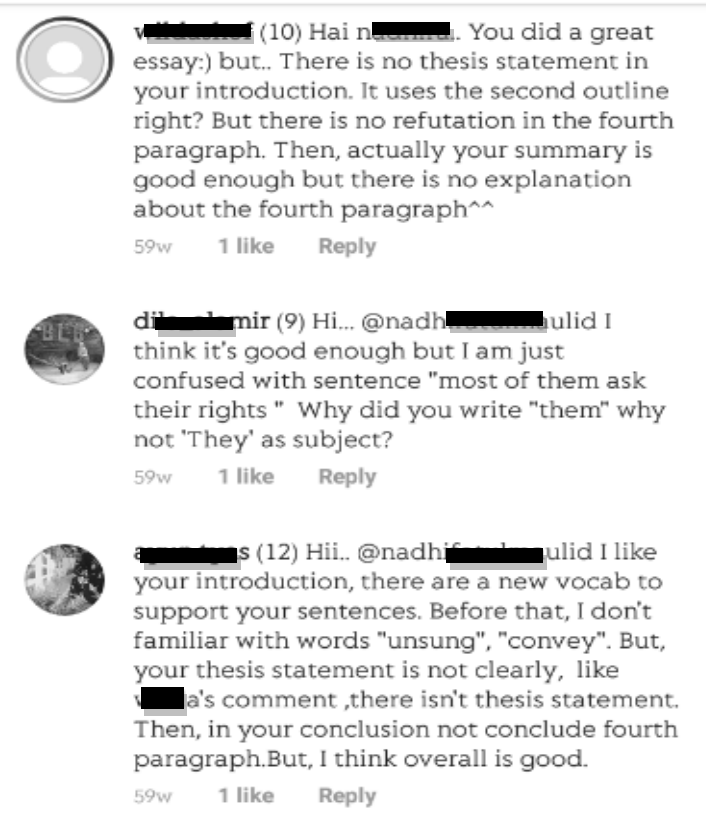

yh (15) your essay is good enough. But there is no thesis statement. And also there are some mistakes. For example, in paragraph 3 you should write "teaching license", not "teacher license" 59w 1 like Reply

ev_an (13) Your essay is good but, I found a bit of problem in the introductory paragraph. I think that the thesis statement in the introductory paragraph is not clear enough. Maybe you can improve that to be better introductory paragraph :) 59w 1 like Reply

$\mathrm{fb}$ (14) There is no thesis statement in introdoctury but overall is god job $\mathrm{N}$ 59w 1 like Reply support your sentences. Before that, I don't amiliar with words "unsung", "convey". But, your thesis statement is not clearly, like paragraph.But, I think overall is good.

w madd (11). halo nd your essay is good, although in the introduction there is no thesis statement, maybe in the next time you can revise again. good luck $59 \mathrm{w} 1$ like Reply

Figure 2. Students' Feedbacks

Various feedbacks were contributed to the writer (S8) by each peer as presented in the figure above. The first and the third peers (S10, S12) critiqued the introduction paragraph because there was no thesis statement provided and no clear refutation in the fourth paragraph. The last, the peer also commented that the writer did not cover the idea of the fourth paragraph in the conclusion. All the feedbacks delivered by peers above were correct; however, the writer (S8) had included the refutation in the fourth paragraph started from a word of beyond that. Unfortunately, the writer did not use clear transitions of contrast such as however, although, or even though to indicate that the writer was going to refute the counter argument stated previously.

In the second feedback, the peer (S9) critiqued the error sentence structure based on her opinion although the writer's sentence was correct to use them instead of, they as subject. The phrase of Most of them was a subject in the sentence and followed by ask as a verb. The next peer (S15) commented on the unclear thesis statement in the introduction as delivered by the previous peers and she also critiqued the error writing of phrase of teacher license by providing teaching license as the correct one. The last three peers also critiqued the unclear thesis statement in the introduction without providing feedbacks of how and what thesis statement is appropriate to present in the introduction. In short, all peers had interacted well in the activity of giving feedback to the writer shown by the way they critiqued and provided feedback on each error. The peers also commended the writer's work before commenting by expressing "you did a great essay, it is good enough, and your essay is good." The writer also indicated 
Elda Yulia Ryandini, Oikurema Purwati, Suharsono, Are Peer Feedback ...

good responses for the peers who commented on some of errors in her essay for improvement; for instance, in the way the writer expressed her gratitude in the last comment "Thanks for your correction guy. I'll revise soon."

To look at the other students' abilities in delivering feedbacks on the writer's argumentative writing, another argumentative essay from a student (S9) will be displayed below.

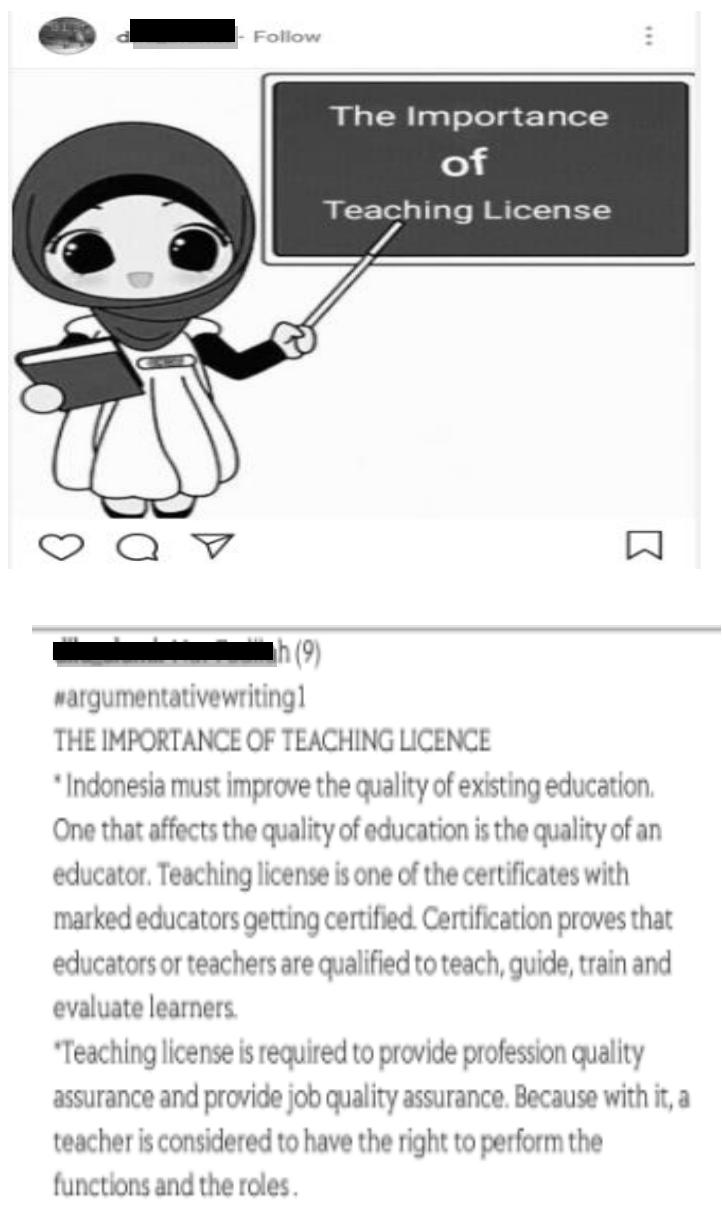
* Need to be known The United States and England. Every individual who wants to become a teacher must take the test to obtain teaching license. Those who are graduated then deserve to be teachers. This two-state system is practiced in Indonesia under existing laws.
- Some people argue that teaching license is not necessary. This opinion is not justified and even contrary to the law of the Republic of Indonesia number 14 of 2005 on teachers and lecturers. Actually teaching license is needed in teaching because it can work legally as a teacher and is recognized as a quality teacher.
* There are also the argue that the quality of a teacher is not measured they get teaching license. Actually teaching license is only given to teachers who satisfy professional standards of teachers, qualified teachers, competence and teachers that produce good student learning achievement. ${ }^{*}$ The conclusion is Teaching license is very important in teaching practice because it is a formal proof of recognition given to teachers as work force.
×Sources: https:/www.alleducationschools.com/degrees- licensing/teacher-certification/
https://www.google.co.id/search?ie=UTF-8\&client=ms-android- samsung\&source=android-browser\&q=tentang+guru+dan +dosen\&gws_rd=cr\&dcr=0\&ei=dX4aWpGkI4HLOATJjpzoAg

Figure 3. Student's Argumentative Essay

The student (S9) provided 4 body paragraphs with 2-3 sentences on each. In body paragraph, the generic structure was not as proposed by Oshima and Hogue which only has 3 body paragraphs completed by counter argument and refutation. Unfortunately, there were no counter arguments and refutations exemplified in the 1 st and the 2nd body paragraphs; however, she provided counter argument and refutation only in the 3rd and 4th paragraphs despite only by short sentences. The student refuted the incomprehensive counter argument and lack of facts. 
Also, there were no transitions of contrast commonly used in the essay such as however, although, even though to indicate the refutation in all body paragraphs. In the last paragraph for the conclusion, the sentence was only one sentence and it did not cover all information discussed in the previous paragraphs. The student should add some more sentences to ease the readers going through the ideas discussed in the essay.

After discussing the student's essay entitled "The Importance of Teaching License" presented on Instagram above, let's take a look at some peers who also offered various feedbacks for the writer (S9) as exemplified below.

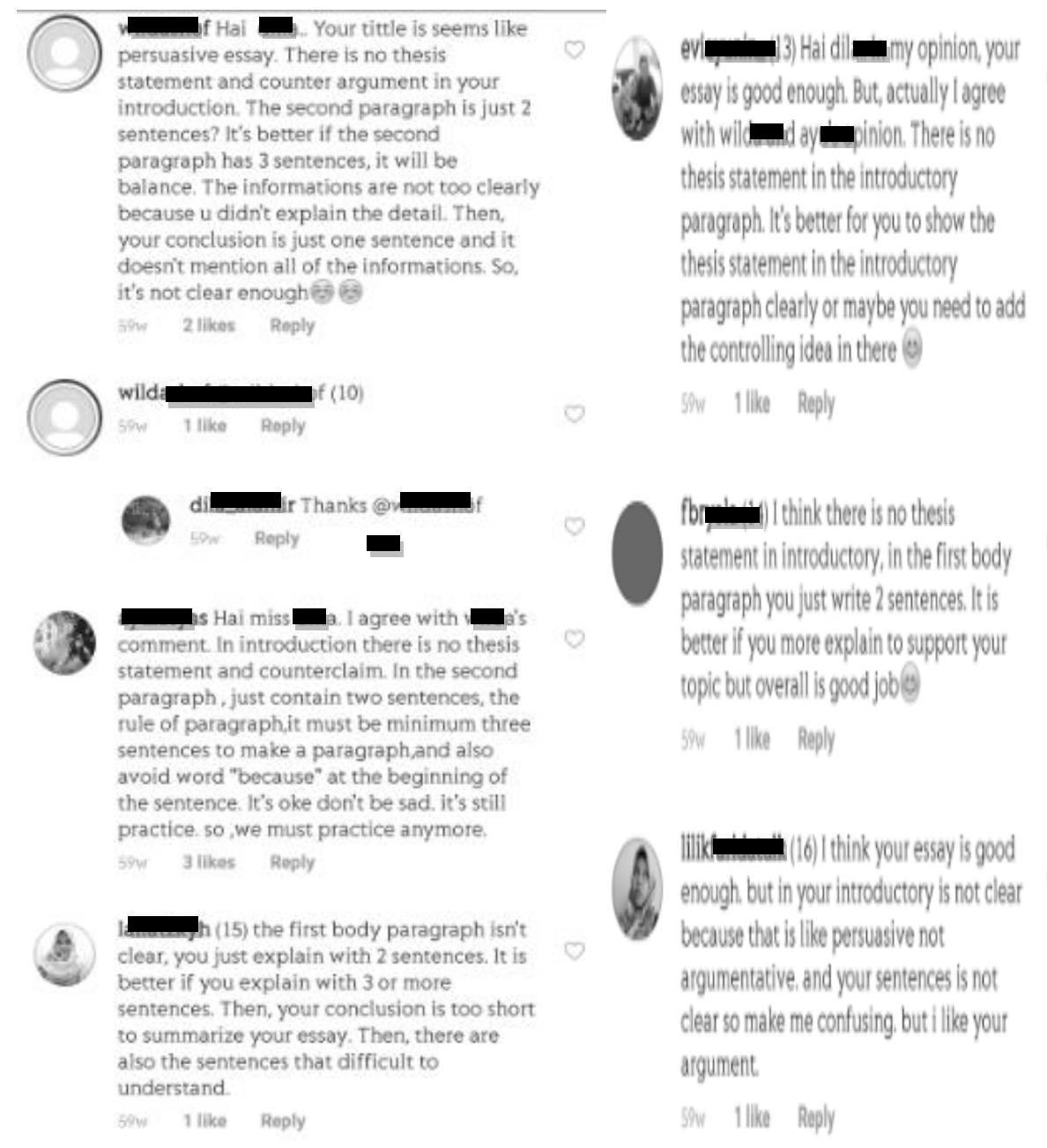

Figure 4. Students' Feedbacks

From student's (S9) essay, the common comments were delivered for not debatable title, no thesis statement and counter argument in introduction, and short sentences in body and conclusion paragraphs. The title was still not debatable because the writer tended to persuade the readers on the importance of having teaching license. In introduction paragraph, student 
did not serve a thesis statement and counter argument instead of only explaining the issue of teaching license. The student mostly wrote short sentences which could not deliver much information for the readers. Unfortunately, from all feedbacks delivered above, there was 1 student (S11) who did not comment on the essay of (S9).

The following argumentative essay is from a student (S16) who brings a title of "Teachers Should Need to be Licensed to Teaching". The various feedbacks conveyed by some peers will be depicted below.

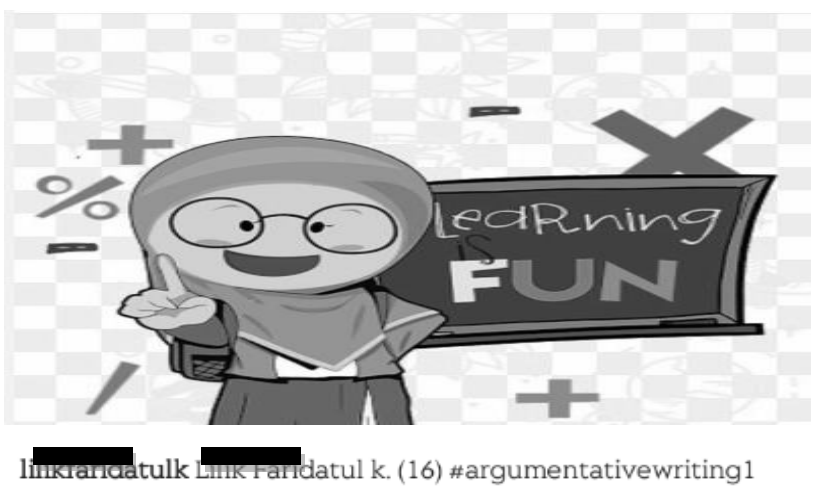

TEACHERS SHOULD NEED TO BE LICENSED TO TEACHING ${ }^{*}$ Teaching is a social job that involves constant interaction with others. Teaching license is important to be more quality for teachers. However, some people believe that teachers sholud be not be used teaching license to practice their teaching. This essay will explain about advantages teachers earn teaching license to practice teaching. "The first advantages is that it will help teachers to acceptance join in the school. Using current teaching license is important because without teaching license program, teacher can not join in the best school expected and that it make easier to join with them. *If teachers want to join in proffessional school, teacher should be develop their knowledge and preparation for the esential skills. So teaching license will help teachers to develop communication skills and make teachers to proffessional teachers. And that is can be to standars indicating that the teaacher should be have permission from the government. "License teaching can be use in overseas. While it is true, but each state has spesific requirements that must be met before you can teach there. So if teachers want to scholarship in each state the teaching license is very helpful with the teachers has teaching licensed. (continue in comment)

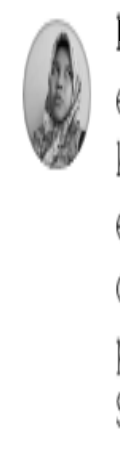

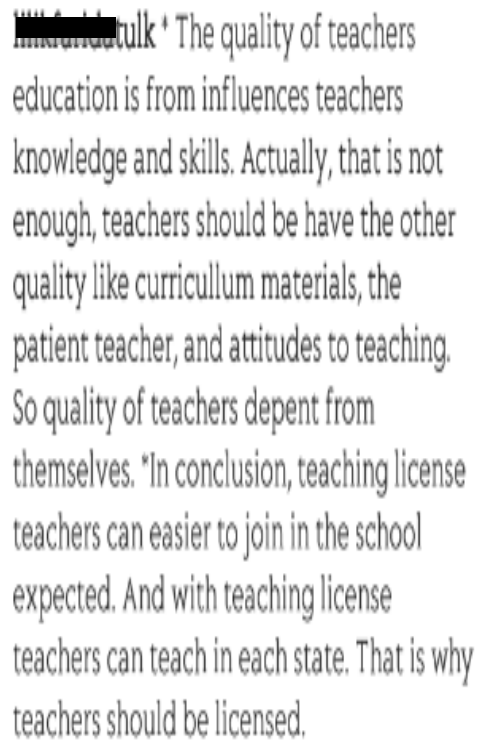

59 W Reply

Figure 5. Students' Argumentative Essay

The student (S16) wrote 6 paragraphs consist of 1 introduction paragraph, 4 body paragraphs, and 1 conclusion paragraph. The student did not follow the outline provided by the lecturer that should be only 5 paragraphs in a whole. Also, the argumentative essay written by the student was not enough providing information about the topic taken by the student to discuss “Teachers Should Need to be Licensed". The student only wrote short sentences 
on each paragraph and did not present the counter argument in each body paragraph. Some ideas also are not consistent whether the student agreed or disagreed with the issue she wrote.

To know various opinions related to the essay written above, there are some feedbacks conveyed by peers as exemplified below.
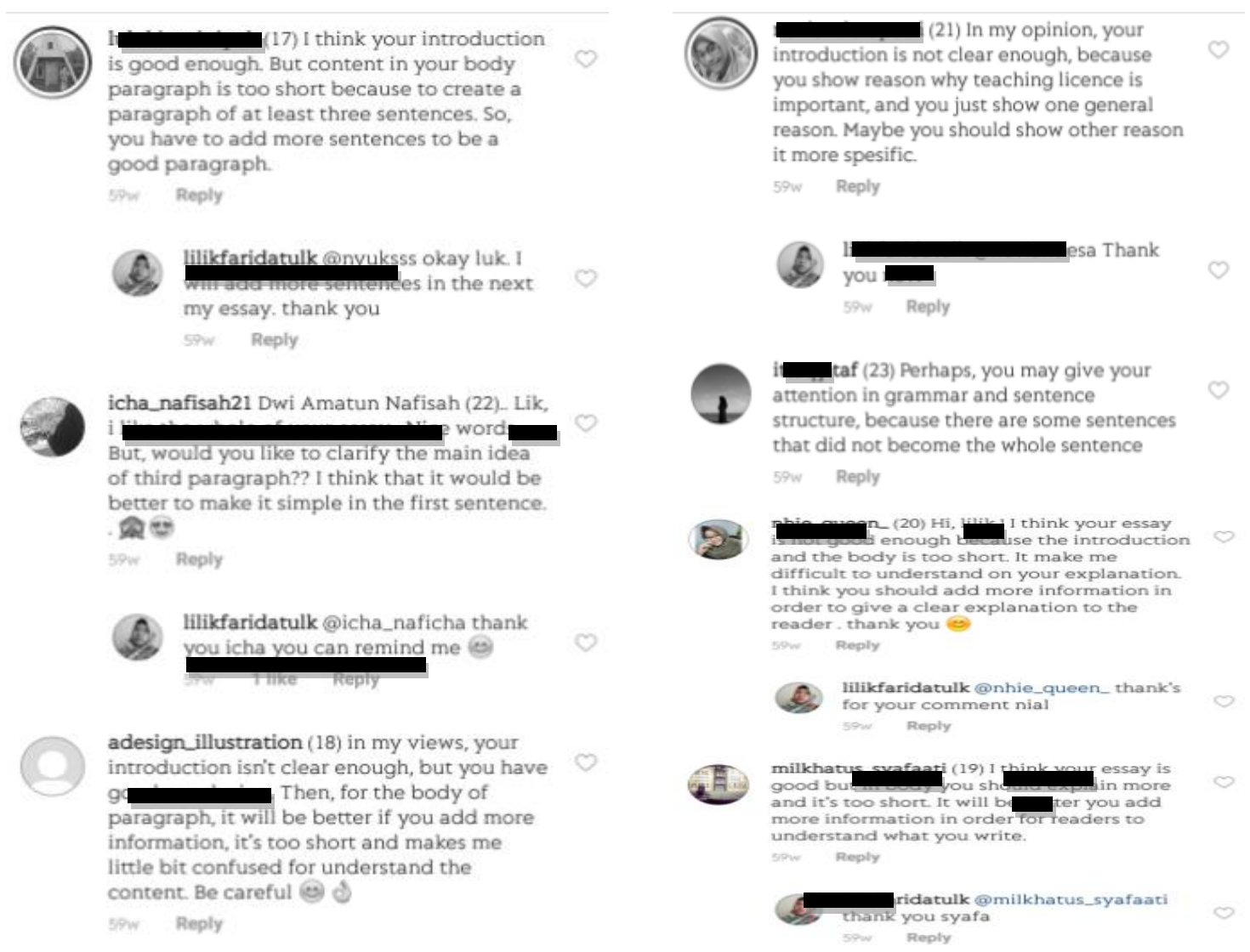

Figure 6. Students' Feedbacks

Various comments were found from peers related to student's (S16) above such as incomplete ideas in the introduction, some error grammars and sentence structures, and body paragraphs are too short. The introduction paragraph did not present good thesis statement which showed that the writer wanted to argue the topic she wrote, but the body paragraphs were not enough to present the ideas because there were only 2 sentences without clear counter arguments and refutations.

From the 3 representative argumentative essays presented above, it can be summarized that feedbacks mostly given by peers in online argumentative writing are: 
Elda Yulia Ryandini, Oikurema Purwati, Suharsono, Are Peer Feedback ...

\begin{tabular}{|c|c|c|c|c|c|c|c|}
\hline \multirow{2}{*}{ Wr. } & \multicolumn{7}{|c|}{ Feedbacks } \\
\cline { 2 - 8 } & TS & Ref & Con & SS & Tit. & CA & Sen \\
\hline S9 & 4 & - & 2 & - & 2 & 2 & 4 \\
\hline S12 & 6 & 1 & 2 & 3 & - & - & - \\
\hline S16 & 3 & - & - & 2 & - & - & 4 \\
\hline
\end{tabular}

*) Wr. $=$ Writer *) SS = Sentence Structure

*) Tit. $=$ Title $\quad *$ CA $=$ Counter Argument

*) Sen $=$ Sentence $*$ ) TS $\quad=$ Thesis Statement

*) $\operatorname{Ref}=$ Refutation $*$ Con $=$ Conclusion

From the representative data above, most peers delivered feedbacks on no thesis statements presented in the introduction paragraph; not summarize the body paragraphs in conclusion; errors sentence structures, not debatable titles, no counter argument in the body paragraphs, and inadequate sentences in body paragraphs and conclusion.

\section{The Essences of Getting Peer Feedbacks for Online Argumentative Writing}

Discussing the essence of peer feedback, it gives many advantages as declared by Tsao et al., (2017, p. 1) such as encouraging students' motivation and making certain of linguistic accuracy. Some other advantages of having peer feedback in a classroom activity also stated by some writers such as improving their interaction skill, increasing students' confidence (Roberts, 2006, p. 2), encouraging students' contribution in developing students' writing skill (Nguyen, 2016, p. 76), developing critical reflection, listening to and acting on feedback, assessing and provide feedback sensitively on others' works (Liu \& Carless, 2006, p. 289). Students will be able to learn from each other by not only having a book and teacher's feedback. They, however, are able to be critical, develop their idea, and learn many new things independently. Initially, teachers prepare the material, divide the student to whom they will deliver the feedback, and make the guidelines of the feedback to limit their discussion. Later, the teacher is able to monitor and discuss the material together in the classroom.

Although there are many speculations related to learning using online media or social media such as disturbing students' learning time and showing students' to many useless websites, this study, however, supports that there were no problems related the practice of peer feedbacks undertaken in online learning process.

The findings of students' answers related to the essence of getting peer feedback in online argumentative writing were positive proved by students' enthusiastic derived from interview; for example, "writing argumentative essay on Instagram is one of great activities because I can get peer feedbacks for correcting and becoming aware of my lacks and mistakes in argumentative writing and I can learn better in future"; "when I write argumentative essay on Instagram, many people can read it and give comments on my writing and I think it is very nice because from the feedback I can know my mistakes that should I correct in future"; and the last, "I like writing argumentative essay on Instagram because my followers can know it 
and they can correct my mistakes in writing. I change and edit my writing as the feedbacks given and I ask or ignore feedbacks which are confusing."

From the findings above, students stated that having Instagram writing and getting feedback from peers are essential and positive for their future improvement such as encouraging students' contribution in developing students' writing skill (Nguyen, 2016, p. 76), and developing critical reflection, listening to and acting on feedback, assessing and provide feedback sensitively on others' works (Liu \& Carless, 2006, p. 289) and they can interact with each other as stated by Roberts (2006, p. 2).

These findings also answer the negative speculations for learning using social media as supported by Malia (2014, p. xxxv) that a social media can motivate students in learning because they are comfortable to have a place for communication with peers and lecturers as an educational purpose. There are no problems as long as the teachers can design online or classroom learning well. Therefore, applying the activity of peer feedbacks offer essences since it is well-structured to be a meaningful activity both online and classroom learning.

\section{E. CONCLUSION}

Errors in learning a foreign language must be experienced by every student as they learn many new things such as in learning writing of argumentative essay. It, moreover, will be experienced differently when the activities occurred in online sites and peers take part to give feedback on it. This study is aimed at finding out feedbacks given by peers in online argumentative writing; and the essences of getting peer feedbacks for online argumentative writing.

There are various feedbacks given by peers such as no thesis statement in introduction, short sentences in body and conclusion paragraphs, incomplete ideas in introduction, error grammars and sentence structures, no clear counter arguments and refutations in body paragraphs, no refutation in body paragraph, not cover idea of body paragraph in conclusion, not debatable title, and not confusing position whether agree or disagree with the topic. From the analysis discussed previously regarding feedbacks mostly given by peers in online argumentative writing, the results showed that the students mostly did not present a thesis statement in introduction, wrote unclear thesis statement as the core point to come up to body paragraphs, wrote short sentences in each paragraph which caused the reader difficult to point the ideas and to convince the readers about the writers' arguments. As a result, the writers got many improvements after getting feedback from peers in the next argumentative essay project. 
For the last, after having the activities of peer feedbacks in online argumentative above, students conveyed their opinion regarding the essences of getting peer feedbacks for online argumentative writing. Their answers were fully positive as they declared that peer feedback can help them to correct, edit, and change their writing, make them aware of the lacks and errors in argumentative writing. They were motivated in responding to the activity of peer feedbacks because they got the feedbacks based on their difficulties and it was useful for them. The students also can apply the good netiquette among others such as commending the writer's work before commenting by expressing “you did a great essay, it is good enough, and your essay is good" and the writer also indicated good responses for the peers who commented on some of errors in their essay for improvement; for instance, in the way the writer expressed her gratitude in the last comment "Thanks for your correction guy. I'll revise soon." It can be concluded that it is good to use technology for learning process and peer feedbacks activities done in online argumentative writing are essential.

\section{REFERENCES}

Al-Ali, S. (2014). Embracing the Selfie Craze: Exploring the Possible Use of Instagram as a Language mLearning Tool. Issues and Trends in Educational Technology, 2(2), 1-16. Retrieved from: https://journals.uair.arizona.edu

Bach, S., Haynes, P., \& Smith, J. L. (2007). Online Learning and Teaching in Higher Education.UK: the McGraw-Hill companies.

Bogdan, R. C. \& Biklen, S. K. (2007). Qualitative Research for Education: An Introduction to Theory and Methods (Fifth Edition). USA: Pearson.

Brown, H. D. (2004). Language Assessment: Principles and Classroom Practices. United States: Pearson Education .

Bryman, A. (2012). Social Research Methods (4th Edition). USA: Oxford University Press.

Cohen, L., Manion, L., \& Morrison, K. (2000). Research Methods in Education (5th Edition). London: Routledge Falmer.

Dabbagh, A. (2017). The Effect of Dialogue Journal Writing on EFL Learners' Descriptive Writing Performance: A Quantitative Study. International Journal of Applied Linguistics \& English Literature, 6(3), 71-80. doi:10.7575/aiac.ijalel.v.6n.3p.71

Daly, B. (1997). Writing Argumentative Essays. ESL Planet.

Galette, A. (2013). Mastering the Semi-Structured Interview and Beyond (From Research Design to Analysis and Publication). USA: New York University Press.

Grami, G. M. A. (2012). Online Collaborative Writing for ESL Learners Using Blogs and Feedback Checklists. Canadian Center of Science and Education , 5(10), 43-48. Retrieved 
from: www.ccsenet.org

Hattie, J., \& Timperley, H. (2007). The Power of Feedback. Review of Educational Research, 77(1), 81-112. doi: 10.3102/003465430298487

Horning, A. S. (1987). Teaching Writing as Second Language. United States of America: Southern Illinois University Press.

Hyland, K. (1990). A Genre Description of the Argumentative Essay. RELC Journal, 21(66), 66-78. doi:10.1177/003368829002100105

Kelly, R. (2015). An Exploration of Instagram to Develop ESL Learners' Writing Proficiency. British Council ELT Master's Dissertation Awards: Commendation. Retrieved from: https://englishagenda.britishcouncil.org/sites/default/files/attachments/dissertation_fo r_publication_ulster_university.pdf.

Listiani, G. (2016). The Effectiveness of Instagram Writing Compared to Teacher Centered Writing to Teach Recount Text to Students with High and Low Motivation (The Case of Eight Grade Students in SMP Kesatrian 1 Semarang in the Academic Year of 2015/2016). Journal of English Language Teaching, 5(1), 1-8. Retrieved October 23, 2017, from http://journal.unnes.ac.id/sju/index.php/elt.

Liu, N.F \& Carless, D. (2006). Peer Feedback: The Learning Element of Peer Assessment. Teaching in Higher Education: Routledge, 279-290. Retrieved from:

http:// citeseerx.ist.psu.edu/viewdoc/download?doi=10.1.1.708.2822\&rep=rep1\&type= pdf.

Mallia, G. (2014). The Social Classroom: Integrating Social Network Use in Education (Part of the Advances in Educational Technologies and Instructional Design Series). USA: Information Science Reference (IGI Global).

Mihalicek, V., \& Wilson, C. (2011). Language Files: Materials for an Introduction to Language and Linguistics. Colombus: The Ohio State University Pess.

Miles, M.B., Huberman, A. M., \& Saldana, J. (2014). Qualitative Data Analysis: A Methods Sourcebook (Third Edition). USA: Sage Publications.

Mubarokah, A. (2017). The Use of Instagram to Motivate Students' Writing Desriptive Text. Digital Library UIN Sunan Ampel. Retrieved October 22, 2017, from http://digilib.uinsby.ac.id: http://digilib.uinsby.ac.id/id/eprint/19143.

Nguyen, H. T. (2016). Peer Feedback Practice in EFL Tertiary Writing Classes. Canadian Center of Science and Education, 9(6), 76-91. Retrieved from: http://dx.doi.org/10.5539/elt.v9n6p76

Purcell, M. A. (2012). The Network Library: A Guide for the Educational Use of Social Networking Sites. United States of America: Linworth.

Oshima, A., \& Hogue, A. (2006). Writing Academic English Fourth Edition (Longman Academic Writing Series, Level 4). London: Pearson Longman. 
Elda Yulia Ryandini, Oikurema Purwati, Suharsono, Are Peer Feedback ...

Roberts, T.S. (2006). Self, Peer and Group Assessment in E- Learning. United States of America: Information Science Publishing.

Salih, A. R. A. (2013). Peer Response to L2 Student Writing: Patterns and Expectations. Canadian Center of Science and Education, 6(3), 42-50. Retrieved from: http://dx.doi.org/10.5539/elt.v6n3p42

Statista. (2019) Instagram - Statistics and Facts. Retrieved from: https://www.statista.com

Tsao, J.J., Tseng, W.T., \& Wang, C. (2017). The Effects of Writing Anxiety and Motivation on EFL College Students' Self-Evaluative Judgments of Corrective Feedback. SAGE, $\quad 0(0), \quad$ 1-23. Retrieved from: https://doi.org/10.1177/003329411668712 